\title{
Meeting Chairs Appointed for 1988 MRS Spring Meeting
}

\author{
15 Technical Symposia Provide Diverse Topical Coverage
}

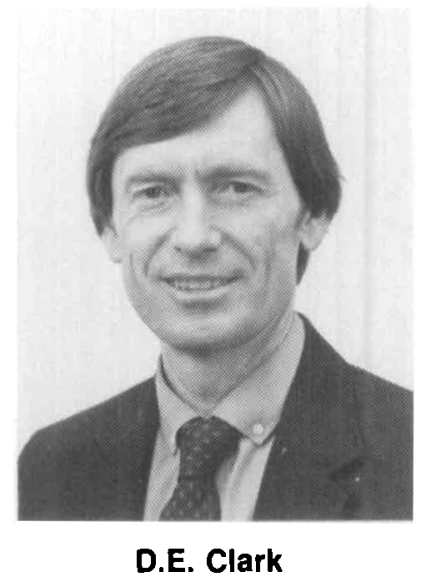

David E. Clark, Clifton W. Draper, and Chain T. Liu have been appointed Meeting Chairs for the 1988 MRS Spring Meeting, scheduled April 4-9, 1988 in Reno, Nevada. The meeting program features 15 technical symposia highlighting new horizons as well as covering recent advances in fundamental materials research topics.

"The Meeting Chairs for the 1988 MRS Spring Meeting were charged by the program committee to diversify the topical coverage of the symposia," said Clif Draper. "I think you will agree that we have produced the most diversified topical symposia coverage to date," continued Draper, citing Symposium B on Materials for Controlled Release Environments, Symposium C on Process Diagnostics, and Symposium $\mathrm{L}$ on Materials Issues in Art and Archeology. While the popular and "hot news" areas will be thoroughly examined, this meeting will also offer a selection of interesting specialty topics never before offered at an MRS annual meeting.

David E. Clark is a professor in the Department of Materials Science and Engineering at the University of Florida in Gainesville. He directs a research program consisting of both basic science and applied engineering, teaches several undergraduate and graduate courses in ceramics, and is Co-director of the Advanced Materials Research Center.

His areas of specialization include materials engineering, ceramics, composites, glass, environmental degradation of glass and ceramics, coatings, and nuclear waste materials. His current research involves the chemical synthesis of ceramic coatings and composites (sponsored by General Motors and AFOSR) and glass corrosion (sponsored by Savannah River Laboratory).

Clark, a Licensed Professional Engineer in Florida and a member of several honor

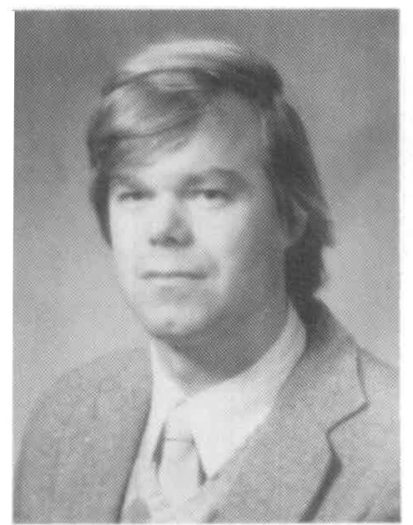

C.W. Draper

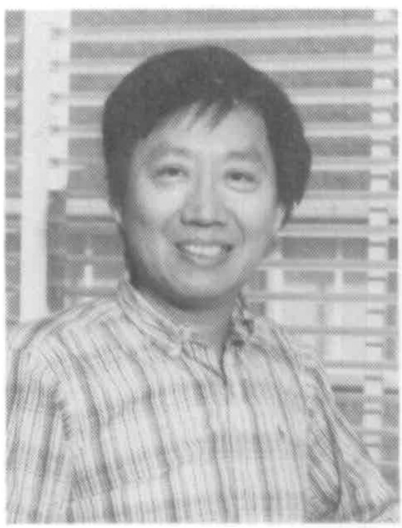

C.T. Liu societies, is chair of the Florida Section of the American Ceramics Society (ACerS). $\mathrm{He}$ is vice chair of the Engineering Ceramics Division of ACerS, program chair for the division's 89th Annual Meeting, and has been chair of the Symposium on $\mathrm{Nu}$ clear Waste Management sponsored by ACerS. ciety, Clark was a symposium organizer for the 1986 MRS Spring Meeting symposium on Better Cermics Through Chemistry.

Clif Draper is supervisor of the Optical Materials Group at AT\&T Engineering Research Center, Princeton, NJ. His earliest research interests were in energy transfer at solid surfaces; and in thermal emission, thermal conduction, and gas-surface energy exchange at the surface of metals and group V semimetals.

His later activities involved research and development of laser methods used in surface modification, the application of these methods to the discovery of new materials (stainless copper alloys, diffused precious metals, metallic glasses, and alloyed amorphous submicron particles). He holds two U.S. patents as a result of these activities.

Draper's most recent research is materials research in support of optical materials activity and also includes the high temperature diffusion of dopants and impurities, and flame synthesized metallic and nonmetallic oxides. His current interactive and collaborative efforts with Bell Laboratories colleagues involve surface characterization through TEM, RBS, channeling, Auger spectroscopy, SEM, and $x$-ray diffraction.

A member of the State of New Jersey Commission on Science and Technology Peer Review Panel, Draper is also active in NATO schools and an active speaker in local elementary schools. He is a member of the Materials Research Society and has served it in numerous capacities. He has
A member of the Materials Research So- presented research results in about ten different technical symposia, has been chair of the Corporate Participation and Finance committees, and was Treasurer in 1985 and 1986.

Chain T. Liu is the leader of the Alloying Behavior and Design Group at Oak Ridge National Laboratory, Tennessee. In 1985 he was designated as a Corporate Fellow of Martin Marietta Energy Systems, Inc., which operates ORNL for the U.S. Department of Energy. His research interests are in alloy development and design, high temperature deformation and fracture, precious metal alloys, refractory alloys, and ordered intermetallic alloys. He has contributed to more than 80 technical papers in these fields and has been granted 12 U.S. patents and patent disclosures for the development of ordered intermetallic alloys and precious metal alloys for high temperature structural applications.

Liu has received several awards and citations. A Fellow of the American Society for Metals, he has won two "IR-100 Awards" from Research and Development Magazine. He received the Honorary Platinum Membership from the International Precious Metals Institute and was the first recipient of the institute's Henry J. Albert Award in 1980. He has received awards from NASA and the U.S. Department of Energy for contributions to the development of special structural alloys for space applications. In 1985, he was named the "Scientist of the Year" by Martin Marietta Energy Systems and winner of the Martin Marietta Corporate Jefferson Cup Award. Recently, Brown University also honored Liu as a Distinguished Alumnus for his scientific and technological accomplishments.

The symposia planned for the 1988 Spring Meeting are as follows:

Symposium A: Heteroepitaxy on Silicon Technology

Continued 
Symposium B: Materials for Controlled Release Environments

Symposium C: Process Diagnostics

Symposium D: Diamond and Diamondlike Materials Synthesis

Symposium E: Amorphous Silicon Technology

Symposium F: Adhesion at Surfaces

Symposium G: High-Temperature High-

Performance Composite Materials
Symposium H: Better Ceramics Through Chemistry

Symposium I: Interfacial Structure,

Properties, and Design

Symposium J: Science and Technology of Refractory Alloys

Symposium K: High-Temperature Superconductors

Symposium L: Material Issues in Art and Archeology
Symposium M: Microwave Processing of Materials

Symposium N: Materials Stability (Environmental Degradation)

Symposium P: Advanced Surface Processes for Optoelectronics

Symposium X: Frontiers of Materials Research

\section{Corporate Participation Program}

\section{Materials Research Society}

Organizations interested in influencing the growth and direction of interdisciplinary, basic research in materials are invited to take part in the MRS Corporate Participation Program as Corporate Affiliates. The program links the efforts of two key groups toward advancing development of materials of technological importance-organizations responsible for pioneering development and application of advanced materials and the Materials Research Society, which provides an interdisciplinary forum for the exchange of technical information among materials scientists in industry, government, and academia.

Corporate Affiliates help the Society in its mission by providing advice on topics to be addressed at its meetings. Their financial contributions enable the Society to address these topics in a timely and thorough manner and to publish and disseminate scientific data quickly. The result of this cooperative focus is an acceleration in and broadening of the scientific understanding in a particular area. Each Corporate Affiliate is kept abreast of the Society's goals and activities through a corporate representative.

MRS Corporate Affiliates play a vital role in the Society by ensuring that the Society's technical programs are responsive to the interests of the research community and by broadening the financial base of the Society. MRS is the only scientific association devoted to promoting research on materials from a multidisciplinary perspective. The Society's rapid growth since 1973 is due to its unique method of matching the needs of industrial research organizations and to its quick response to changing interests in the materials science community.

\section{MRS Corporate Affiliate Benefits}

- Two subscriptions to MRS BULLETIN, the Society's news publication (one copy for the corporate affiliate representative, one copy for the company library).

- Recognition of support in all promotional material for MRS Fall and Spring Meetings.

- Advance notification of meeting programs and events.

- Advance consultation on topical program contents.

- Opportunity to purchase symposium proceedings at meeting participant prices.

- Free employment ads in MRS BULLETIN.

- Opportunity to display corporate literature free of charge at MRS meetings.

- Opportunity to participate in job placement services free of charge at MRS meetings.

- Reduced booth rental rates at MRS equipment exhibits.

- Opportunity to meet with Society Officers on topics of mutual concern.

For further information about the MRS Corporate Participation Program, contact:

Michael Quick, Chair, Corporate Participation Committee, Engelhard Corporation, Menlo Park, CN28, Edison, New Jersey 08818; telephone (201) 321-5590.

or

John B. Ballance, Executive Director, Materials Research Society, 9800 McKnight Road, Suite 327, Pittsburgh, PA 15237; telephone (412) 367-3003. 